\title{
Penggunaan Media Gambar pada Mata Pelajaran IPA Materi Ciri-Ciri dan Kebutuhan Makhluk Hidup Dapat Meningkatkan Hasil Belajar Siswa Kelas III SDN. No. 031/ XI Kampung Dalam Tahun 2016/2017
}

\author{
Erzos Maidar ${ }^{1}$ \\ Guru di SDN. No. 031/XI Kampung Dalam ${ }^{1}$ \\ Kecamatan Hamparan Rawang, Kota Sungai Penuh, Provinsi Jambi
}

\begin{abstract}
This study aims to improve learning outcomes of third grade students in science subjects, especially on the material characteristics and needs of living things in the SDN. No. 031/XI Kampung Dalam year 2016/2017 image media. The type of research conducted is classroom action research conducted in two cycles (Cycle I and Cycle II) and each cycle consists of two meetings with four activities, namely planning, implementation, observation, and reflection. This research involved 27 students of third grade at SDN. No. 031/XI Kampung Dalam, Hamparan Rawang Subdistrict, Sungai Penuh City, Jambi Province. The study was conducted from July to November of 2016. Data were collected through objective test and observation. Data was processed by descriptive analysis and simple statistical test. The results showed that the use of image media can improve student learning outcomes. This increase can be seen from the increase of the average score and the percentage of students' learning mastery. The average score of students before action was 50,74 increased to 64,07 in Cycle I, and increased again to 74,81 in Cycle II. Similarly, the percentage of learning mastery. Percentage mastery of students before action is given 48,15\% increased to 62,96\% in Cycle I and increased again to $85,19 \%$ in Cycle II. Thus, the use of image media can improve the learning outcomes of third grade students in science subjects, especially on the material characteristics and needs of living things in the SDN. No. 031/XI Kampung Dalam year 2016/2017.
\end{abstract}

Keywords: elementary school, image media, learning activities, learning outcomes

\section{PENDAHULUAN}

Ilmu Pengetahuan Alam (IPA) berhubungan dengan cara mencari tahu tentang alam secara sistematis, sehingga IPA bukan hanya penguasaan kumpulan pengetahuan yang berupa fakta-fakta, konsep-konsep, atau prinsip-prinsip saja tetapi juga merupakan suatu proses penemuan. Pendidikan IPA diharapkan dapat menjadi wahana bagi peserta didik untuk mempelajari diri sendiri dan alam sekitar, serta prospek pengembangan lebih lanjut dalam menerapkannya di dalam kehidupan sehari-hari. Proses pembelajarannya menekankan pada pemberian pengalaman langsung untuk mengembangkan kompetensi agar menjelajahi dan memahami alam sekitar secara ilmiah.
Pendidikan IPA diarahkan untuk inkuiri dan berbuat sehingga dapat membantu peserta didik untuk memperoleh pemahaman yang lebih mendalam tentang alam sekitar. IPA diperlukan dalam kehidupan sehari-hari untuk memenuhi kebutuhan manusia melalui pemecahan masalah-masalah yang dapat diidentifikasikan. Penerapan IPA perlu dilakukan secara bijaksana agar tidak berdampak buruk terhadap lingkungan. Di tingkat SD/MI diharapkan ada penekanan pembelajaran Salingtemas (Sains, lingkungan, teknologi, dan masyarakat) yang diarahkan pada pengalaman belajar untuk merancang dan membuat suatu karya melalui penerapan konsep IPA dan kompetensi bekerja ilmiah secara bijaksana. 
Penanaman konsep IPA sejak Sekolah Dasar perlu dilakukan. Akan tetapi, dalam pelaksanaannya, banyak guru yang menemukan masalah dalam pelaksanaan pembelajaran IPA. Nur (2010) menemukan masalah dalam pelaksanaan kegiatan pembelajaran IPA di SD Negeri Sidogiri I Kecamatan Kraton Kabupaten Pasuruan. Masalah tersebut adalah hasil belajar siswa yang rendah. Penyebabnya, dalam proses pembelajaran IPA di SD masih menggunakan cara tradisional dimana kegiatan masih berpusat pada guru, monoton dan menjenuhkan. Guru juga masih menggunakan metode ceramah, tanya jawab, pemberian tugas, dan tanpa menggunakan media, sehingga kemampuan siswa dan kreativitas siswa belum tergali. Oleh karena itu perlu adanya pembaharuan dalam meningkatkan kualitas pembelajaran IPA di sekolah khususnya SD.

Ulumiyah (2010) juga menemukan masalah yang sama yaitu rendahnya prestasi belajar IPA siswa kelas II SDN Gunungsari. Rendahnya prestasi belajar IPA diduga karena penerapan model pembelajaran yang kurang tepat dengan karakteristik pelajaran IPA. Pengamatan awal membuktikan bahwa guru dalam pembelajaran IPA hanya menginformasikan konsep-konsep IPA saja pada siswa, padahal IPA berkembang dari mengamati, mencoba memahami apa yang diamati, meramalkan dan akhirnya menyimpulkan. Selain itu, Abdullah (2014) juga menemukan bahwa aktivitas dan hasil belajar dalam pembelajaran IPA masih rendah pada siswa kelas V di SD Inpres Watujara. Rendahnya hasil belajar terindikasi pada persentase siswa yang mencapai ketuntasan nilai ujian tengah semester ganjil tahun 2014 yaitu sebesar 25\%. Hal ini disebabkan dalam proses pembelajaran guru hanya menggunakan buku paket sebagai media. Selain itu, konsep IPA disajikan secara abstrak oleh guru sehingga siswa kurang memaknai materi dan tidak bisa menyimpulkan materi pelajaran. Aktivitas siswa cenderung hanya mendengar dan terkadang mencatat pelajaran yang diberikan guru. Ketika diberi pertanyaan hanya sebagian siswa yang aktif menjawab dan siswa terlihat bosan mengikuti pelajaran di kelas karena semua kegiatan di dalam kelas hanya berpusat pada guru.

Masalah yang sama juga dihadapi oleh guru di Kelas III SDN. No. 031/XI Kampung Dalam tahun 2016/2017 adalah hasil belajar siswa pada mata pelajaran IPA yang rendah. Hasil evaluasi menunjukkan bahwa siswa lebih cenderung bersikap pasif selama kegiatan pembelajaran karena kegiatan pembelajaran berpusat pada guru. Siswa juga kurang antusias selama kegiatan pembelajaran berlangsung. Siswa merasa bosan, mencoret buku catatan, dan juga kurang memperhatikan penjelasan guru. Guru menggunakan metode pembelajaran yang monoton yaitu metode ceramah. Hal ini berdampak pada rendahnya hasil belajar siswa pada mata pelajaran IPA. Hasil tes penjajakan menunjukkan bahwa nilai ratarata yang diperoleh siswa adalah 50,74 dengan jumlah siswa yang tuntas atau memenuhi KKM adalah 13 orang (persentase ketuntasan belajar siswa secara klasikal adalah 48,15\%). Masalah ini perlu diatasi karena hasil belajar merupakan salah satu indikator dalam menilai keberhasilan kegiatan pembelajaran.

Masalah yang dihadapi guru adalah hasil belajar siswa pada mata pelajaran IPA yang rendah. Hasil belajar menggambarkan pemahaman siswa mengenai materi yang telah diajarkan. Dengan demikian, hasil belajar yang rendah mengindikasikan bahwa pemahaman siswa mengenai materi yang telah diajarkan juga termasuk dalam kategori rendah. Hasil evaluasi menunjukkan bahwa salah satu upaya yang dapat dilakukan untuk mengatasi hal tersebut adalah dengan cara memperbaiki kualitas pembelajaran. 
Kualitas pembelajaran dapat diperbaiki melalui penggunaan media pembelajaran yang tepat. Media pembelajaran merupakan alat dan bahan yang membawa informasi atau bahan pelajaran yang bertujuan untuk mempermudah dalam mencapai tujuan pembelajaran (Suprihatiningrum, 2014). Penggunaan media dalam kegiatan pembelajaran bermanfaat karena penggunaan media dapat memperjelas proses pembelajaran, meningkatkan ketertarikan dan interaktivitas siswa, meningkatkan efisiensi dalam waktu dan tenaga, meningkatkan kualitas hasil belajar siswa, memungkinkan proses belajar dapat dilakukan di tempat mana saja dan kapan saja, menumbuhkan sikap positif siswa terhadap materi dan proses belajar, mengubah peran guru ke arah lebih positif dan produktif, mengkonkretkan materi yang abstrak, membantu mengatasi keterbatasan pancaindra manusia, menyajikan objek pelajaran ke dalam kelas, dan meningkatkan daya retensi siswa terhadap materi pembelajaran.

Media pembelajaran yang dinilai tepat untuk menumbuhkan dan mendorong keaktifan siswa dalam kegiatan pembelajaran adalah media gambar. Media berbasis visual memegang peran yang sangat penting dalam poses belajar (Darmodjo, 2009). Media gambar dapat memperlancar pemahaman dan memperkuat ingatan. Gambar sangat penting digunakan dalam usaha memperjelas pengertian pada peserta didik. sehingga dengan menggunakan gambar peserta didik dapat lebih memperhatikan terhadap benda-benda atau hal-hal yang belum pernah dilihatnya yang berkaitan dengan pelajaran. Menurut Darmodjo (2009) Gambar dapat membantu guru dalam mencapai tujuan intruksional, karena gambar termasuk media yang mudah dan murah serta besar artinya untuk mempertinggi nilai pengajaran. Penggunaan media gambar akan menambah pengalaman dan pengertian peserta didik menjadi lebih luas, lebih jelas dan tidak mudah dilupakan, serta lebih konkret dalam ingatan dan asosiasi peserta didik. David (2012) mengemukakan manfaat media visual gambar dalam proses pembelajaran yaitu penyampaian dan penjelasan mengenai informasi, pesan, ide dan sebagainya dengan tanpa banyak menggunakan bahasa-bahasa verbal, tetapi dapat lebih memberi kesan. Nur (2010); Ulumiyah (2010); Kasmawati, Kundera, dan Gagaramusu (2013); Sandra (2013); Rinawati (2013); Abdullah (2014); Surahman, Paudi, dan Tureni (2015); dan Kapugu, Alibasyah, \& Sakung (2016) telah membuktikan bahwa pembelajaran IPA dengan menggunakan media gambar dapat meningkatkan prestasi belajar siswa.

Berdasarkan pemaparan tersebut, penelitian yang berjudul "Penggunaan Media Gambar untuk Meningkatkan Hasil Belajar Siswa pada Mata Pelajaran IPA Materi Ciri-Ciri dan Kebutuhan Makhluk Hidup di Kelas III SDN. No. 031/ XI Kampung Dalam tahun 2016/2017" dilakukan. Penelitian ini bertujuan untuk meningkatkan hasil belajar siswa kelas III pada mata pelajaran IPA khususnya pada materi ciri-ciri dan kebutuhan makhluk hidup di SDN. No. 031/XI Kampung Dalam tahun 2016/2017 dengan menggunakan media gambar.

\section{METODE PENELITIAN}

Penelitian ini merupakan penelitian tindakan kelas (PTK). Penelitian Tindakan Kelas merupakan suatu pencermatan terhadap kegiatan belajar berupa sebuah tindakan yang sengaja dimunculkan dan terjadi dalam sebuah kelas secara bersama (Arikunto, dkk., 2014). Alasan peneliti menggunakan jenis PTK adalah untuk memperbaiki dan meningkatkan kualitas pembelajaran dengan cara menggunakan media gambar sehingga hasil belajar siswa dapat meningkat terutama pada mata pelajaran IPA materi. Arikunto, dkk (2014) mengemukakan empat tahapan dalam 
pelaksanaan PTK, yaitu perencanaan, pelaksanaan, pengamatan, dan refleksi.

Penelitian dilakukan di SDN. No. 031/XI Kampung Dalam, Kecamatan Hamparan Rawang, Kota Sungai Penuh, Provinsi Jambi. Kegiatan penelitian terdiri atas penyusunan proposal penelitian, pengumpulan data, pengolahan data, analisis data, dan penyusunan laporan. Penelitian dilakukan sejak bulan Juli sampai dengan bulan November tahun 2016.

Subjek dalam penelitian ini adalah siswa kelas III semester ganjil tahun pelajaran 2016/2017 di SDN. No. 031/XI Kampung Dalam, Kecamatan Hamparan Rawang, Kota Sungai Penuh, Provinsi Jambi. Jumlah subjek yang terlibat dalam penelitian ini adalah 27 orang siswa. Objek dalam penelitian ini adalah peningkatan hasil belajar siswa kelas III di SDN. No. 031/XI Kampung Dalam pada mata pelajaran IPA, khususnya pada materi ciriciri dan kebutuhan makhluk hidup.

Data hasil belajar siswa dikumpulkan dengan cara pengamatan atau observasi. Observasi merupakan cara untuk menghimpun data atau bahan-bahan keterangan yang dilakukan dengan mengadakan pengamatan dan pencatatan secara sistematis terhadap fenomenafenomena yang sedang dijadikan sasaran pengamatan. Dalam penelitian ini, observasi dilakukan untuk mengamati tingkah laku siswa selama proses pembelajaran berlangsung. Pengumpulan data juga dilakukan melalui tes. Evaluasi hasil belajar jenis tes merupakan cara untuk melakukan proses penilaian dalam bentuk tugas atau serangkaian tugas yang harus dikerjakan siswa atau sekelompok siswa sehingga menghasilkan suatu nilai yang menggambarkan prestasi siswa. Selanjutnya, data yang telah dikumpulkan diolah dan dianalisis dengan menggunakan analisis deskriptif dan uji statistik sederhana.

Indikator keberhasilan dari penelitian tindakan kelas ini adalah peningkatan hasil belajar siswa pada mata pelajaran IPA di kelas III SDN. No. 031/XI Kampung Dalam tahun 2016/2017. Hasil belajar yang diperoleh setiap siswa dibandingkan dengan Kriteria Ketuntasan Minimum (KKM) kompetensi dasar mata pelajaran IPA yang telah ditentukan oleh sekolah diawal tahun pelajaran 2016/2017 yaitu sebesar 60,00.

\section{HASIL DAN PEMBAHASAN Pratindakan}

Sebelum memberikan tindakan, guru mengadakan tes penjajakan terlebih dahulu pada siswa. Hasil tes penjajakan menunjukkan bahwa nilai terendah siswa adalah 30,00 dan nilai tertinggi adalah 70,00 . Nilai rata-rata yang diperoleh 27 orang siswa adalah 50,74. Apabila dibandingkan antara nilai siswa dengan KKM kompetensi dasar maka diperoleh hasil bahwa sebanyak 13 orang siswa telah memiliki nilai yang lebih besar dari pada KKM kompetensi dasar. Artinya, sebanyak 13 orang siswa tuntas. Sisanya, sebanyak 14 orang siswa belum tuntas. Persentase ketuntasan belajar sebesar $48,15 \%$. Hasil ini menunjukkan bahwa hanya separuh siswa yang mampu memenuhi KKM kompetensi dasar. Hasil ini juga mengindikasikan bahwa guru perlu melakukan perbaikan untuk meningkatkan hasil belajar siswa. Cara yang dipilih guru untuk mengatasi masalah ini adalah melalui penggunaan media pembelajaran. Media yang digunakan adalah media gambar. Penggunaan media diharapkan dapat meningkatkan hasil belajar siswa. Hasil tes penjajakan disajikan pada Tabel 1. 
Tabel 1 Hasil tes penjajakan

\begin{tabular}{cllll}
\hline No & \multicolumn{1}{c}{ Nama Siswa } & KKM & Nilai & \multicolumn{1}{c}{ Keterangan } \\
\hline 1 & Alan Malilo Putra & 60,00 & 40,00 & Tidak Tuntas \\
2 & Anggun Permata Sari & 60,00 & 60,00 & Tuntas \\
3 & Arif Okta Saputra & 60,00 & 70,00 & Tuntas \\
4 & Aulia Marliani & 60,00 & 50,00 & Tidak Tuntas \\
5 & Aditya Tri Wardana & 60,00 & 30,00 & Tidak Tuntas \\
6 & Azzahra Syakilla & 60,00 & 40,00 & Tidak Tuntas \\
7 & Fadhli Alfitra & 60,00 & 60,00 & Tuntas \\
8 & Fadhil Herya Pernanda & 60,00 & 40,00 & Tidak Tuntas \\
9 & Fuji Rahayu Liata & 60,00 & 70,00 & Tuntas \\
10 & Halim Maulana & 60,00 & 60,00 & Tuntas \\
11 & Habil Said & 60,00 & 50,00 & Tidak Tuntas \\
12 & Ikral Pernandes & 60,00 & 70,00 & Tuntas \\
13 & Imel Putri Aurelia & 60,00 & 40,00 & Tidak Tuntas \\
14 & Melly Indah Saputri & 60,00 & 60,00 & Tuntas \\
15 & Muh. Andra Ardiansyah & 60,00 & 40,00 & Tidak Tuntas \\
16 & Muh. Hidayat & 60,00 & 30,00 & Tidak Tuntas \\
17 & Naila Saputri & 60,00 & 60,00 & Tuntas \\
18 & Niani Anggraini & 60,00 & 50,00 & Tidak Tuntas \\
19 & Qonita Islamoza & 60,00 & 60,00 & Tuntas \\
20 & Refan Anugrah & 60,00 & 40,00 & Tidak Tuntas \\
21 & Septia Ramadhani & 60,00 & 60,00 & Tuntas \\
22 & Tika Ariski & 60,00 & 60,00 & Tuntas \\
23 & Utari & 60,00 & 30,00 & Tidak Tuntas \\
24 & Unggul Asmaul Husna & 60,00 & 40,00 & Tidak Tuntas \\
25 & Vovi Norewan & 60,00 & 70,00 & Tuntas \\
26 & Vila Abdillah & 60,00 & 60,00 & Tuntas \\
27 & Wawan Askar & 60,00 & 30,00 & Tidak Tuntas \\
& Nilai Tertinggi & & 70,00 & \\
& Nilai Terendah & 30,00 & \\
& Nilai Rata-Rata & 50,74 & \\
& Ketuntasan Belajar & 48,15 & \\
& & &
\end{tabular}

\section{Siklus I}

Siklus I dilakukan pada 4-11 Agustus 2016. Materi yang disampaikan pada siklus I adalah makluk hidup dan tak hidup, makluk hidup bergerak, makhluk hidup bernapas, dan makhluk hidup makan. Kegiatan pada siklus I terdiri atas perencanaan, pelaksanaan, pengamatan, dan refleksi.

Kegiatan pertama dalam siklus I adalah perencanaan. Kegiatan perencanaan terdiri atas merumuskan tujuan pembelajaran, memilih dan mengorganisasi materi ajar, memilih sumber belajar/media pembelajaran,

menyusun skenario/kegiatan pembelajaran, dan menyiapkan alat evaluasi hasil belajar.

Kegiatan kedua dalam siklus I adalah pelaksanaan. Kegiatan pelaksanaan terdiri atas guru mengucapkan salam dan menanyakan keadaan siswa, guru memeriksa kehadiran siswa, guru menyampaikan tujuan pembelajaran, guru menyampaikan skenario pembelajaran yang akan dilaksanakan, guru melakukan apersepsi, guru menyampaikan materi pelajaran dengan menggunakan media gambar, guru membagi siswa dalam kelompok kecil (4-5 orang siswa yang heterogen), guru memberikan tugas untuk 
dikerjakan secara berkelompok, guru mendampingi siswa dalam mengerjakan tugas, masing-masing kelompok menyampaikan diskusi kelompok di depan kelas secara bergiliran, guru memberi kesempatan kepada kelompok lain untuk menanggapi hasil laporan kelompok penyaji, guru bersama siswa membuat kesimpulan kegiatan, guru memberikan gambaran kegiatan berikutnya, guru melakukan evaluasi hasil belajar, dan guru menyampaikan pesan moral.

Kegiatan ketiga dalam siklus I adalah pengamatan yang dilakukan dengan mengamati tingkah laku siswa selama kegiatan pembelajaran. Hasil pengamatan menunjukan bahwa sebagian siswa sudah memperhatikan penjelasan guru dengan antusias, berpartisipasi aktif dalam mengerjakan tugas kelompok, berani menyampaikan hasil di depan kelas, mampu menanggapi penyajian hasil diskusi dari kelompok lain, serta siswa juga mampu menjawab pertanyaan yang ditanyakan oleh guru mengenai materi yang sudah diajarkan. Secara ringkas, hasil pengamatan disajikan pada Tabel 2.

Tabel 2 Hasil pengamatan aktivitas belajar siswa pada Siklus I

\begin{tabular}{clcc}
\hline No & \multicolumn{1}{c}{ Indikator } & Jumlah & Persen \\
\hline 1 & Siswa mendengarkan penjelasan guru dengan antusias & 20 & 74,07 \\
2 & Siswa bekerja sama dalam kelompok & 20 & 74,07 \\
3 & Siswa berani menjawab pertanyaan dari guru & 17 & 62,96 \\
4 & Siswa melaporkan hasil ke depan kelas & 17 & 62,96 \\
5 & Siswa dapat membuat rangkuman pembelajaran & 17 & 62,96 \\
\hline
\end{tabular}

Penilaian juga dilakukan dengan jenis tes. Soal yang diberikan berupa tes objektif dengan jumlah pertanyaan 10 pertanyaan. Hasil penelitian menunjukkan bahwa nilai rata-rata yang diperoleh 27 orang siswa adalah 64,07. Apabila dibandingkan antara nilai siswa dengan KKM kompetensi dasar maka diperoleh hasil bahwa sebanyak 17 orang siswa telah memiliki nilai yang lebih besar dari pada KKM kompetensi dasar. Artinya, sebanyak
17 orang siswa tuntas. Sisanya, sebanyak 10 orang siswa belum tuntas. Persentase ketuntasan belajar sebesar $62,96 \%$. Hasil ini menunjukkan bahwa terjadi peningkatan hasil belajar siswa setelah diberikan tindakan berupa penggunaan media gambar, baik peningkatan pada nilai rata-rata maupun dalam hal peningkatan ketuntasan belajar secara klasikal. Hasil evaluasi disajikan pada Tabel 3.

Tabel 3 Hasil penelitian pada Siklus I

\begin{tabular}{cllll}
\hline No & \multicolumn{1}{c}{ Nama Siswa } & KKM & Nilai & \multicolumn{1}{c}{ Keterangan } \\
\hline 1 & Alan Malilo Putra & 60,00 & 50,00 & Tidak Tuntas \\
2 & Anggun Permata Sari & 60,00 & 70,00 & Tuntas \\
3 & Arif Okta Saputra & 60,00 & 80,00 & Tuntas \\
4 & Aulia Marliani & 60,00 & 70,00 & Tuntas \\
5 & Aditya Tri Wardana & 60,00 & 40,00 & Tidak Tuntas \\
6 & Azzahra Syakilla & 60,00 & 50,00 & Tidak Tuntas \\
7 & Fadhli Alfitra & 60,00 & 70,00 & Tuntas \\
8 & Fadhil Herya Pernanda & 60,00 & 60,00 & Tuntas \\
9 & Fuji Rahayu Liata & 60,00 & 80,00 & Tuntas \\
10 & Halim Maulana & 60,00 & 70,00 & Tuntas \\
11 & Habil Said & 60,00 & 70,00 & Tuntas \\
12 & Ikral Pernandes & 60,00 & 80,00 & Tuntas
\end{tabular}




\begin{tabular}{lllll}
13 & Imel Putri Aurelia & 60,00 & 50,00 & Tidak Tuntas \\
14 & Melly Indah Saputri & 60,00 & 70,00 & Tuntas \\
15 & Muh. Andra Ardiansyah & 60,00 & 50,00 & Tidak Tuntas \\
16 & Muh. Hidayat & 60,00 & 40,00 & Tidak Tuntas \\
17 & Naila Saputri & 60,00 & 80,00 & Tuntas \\
18 & Niani Anggraini & 60,00 & 60,00 & Tuntas \\
19 & Qonita Islamoza & 60,00 & 80,00 & Tuntas \\
20 & Refan Anugrah & 60,00 & 50,00 & Tidak Tuntas \\
21 & Septia Ramadhani & 60,00 & 90,00 & Tuntas \\
22 & Tika Ariski & 60,00 & 80,00 & Tuntas \\
23 & Utari & 60,00 & 40,00 & Tidak Tuntas \\
24 & Unggul Asmaul Husna & 60,00 & 50,00 & Tidak Tuntas \\
25 & Vovi Norewan & 60,00 & 90,00 & Tuntas \\
26 & Vila Abdillah & 60,00 & 70,00 & Tuntas \\
27 & Wawan Askar & 60,00 & 40,00 & Tidak Tuntas \\
& Nilai Tertinggi & & 90,00 & \\
& Nilai Terendah & & 40,00 & \\
& Nilai Rata-Rata & & 64,07 & \\
& Ketuntasan Belajar & & 62,96 & \\
\hline
\end{tabular}

Kegiatan keempat dalam siklus I adalah refleksi. Refleksi dari hasil penelitian adalah sebagai berikut:

1. Peningkatan hasil belajar sudah mulai terlihat baik dari nilai rata-rata maupun dari ketuntasan belajar. Dengan demikian, pemberian tindakan perlu dilanjutkan.

2. Hasil observasi menunjukkan bahwa tidak semua siswa memperhatikan penjelasan guru dengan antusias, berpartisipasi aktif dalam mengerjakan tugas kelompok, berani menyampaikan hasil di depan kelas, mampu menanggapi penyajian hasil diskusi dari kelompok lain, serta juga mampu menjawab pertanyaan yang ditanyakan oleh guru mengenai materi yang sudah diajarkan. Dengan demikian, guru perlu memberikan bimbingan intensif dan mendekati siswa tersebut secara pribadi. Guru juga dapat memberikan motivasi untuk meningkatkan kepercayaan diri dan minat siswa dalam belajar.

3. Berdasarkan hasil siklus I, guru perlu melakukan perbaikan dalam pelaksanaan pembelajaran pada Siklus II.

\section{Siklus II}

Siklus I dilakukan pada 23-30 Agustus 2016. Materi yang disampaikan pada siklus II adalah makhluk hidup tumbuh dan makhluk hidup berkembang biak. Siklus II terdiri atas empat kegiatan yaitu perencanaan, pelaksanaan, pengamatan, dan refleksi.

Kegiatan pertama dalam siklus II adalah perencanaan. Kegiatan perencanaan terdiri atas merumuskan tujuan pembelajaran, memilih dan mengorganisasi materi ajar, memilih sumber belajar/media pembelajaran, menyusun skenario/kegiatan pembelajaran, dan menyiapkan alat evaluasi hasil belajar.

Kegiatan kedua dalam siklus II adalah pelaksanaan. Kegiatan pelaksanaan terdiri atas guru mengucapkan salam dan menanyakan keadaan siswa, guru memeriksa kehadiran siswa, guru menyampaikan tujuan pembelajaran, guru menyampaikan skenario pembelajaran yang akan dilaksanakan, guru melakukan apersepsi, guru menyampaikan materi pelajaran dengan menggunakan media gambar, guru membagi siswa dalam kelompok kecil (4-5 orang siswa yang heterogen), guru memberikan tugas untuk 
dikerjakan secara berkelompok, guru mendampingi siswa dalam mengerjakan tugas, masing-masing kelompok menyampaikan diskusi kelompok di depan kelas secara bergiliran, guru memberi kesempatan kepada kelompok lain untuk menanggapi hasil laporan kelompok penyaji, guru bersama siswa membuat kesimpulan kegiatan, guru memberikan gambaran kegiatan berikutnya, guru melakukan evaluasi hasil belajar, dan guru menyampaikan pesan moral.
Kegiatan ketiga dalam siklus II adalah pengamatan. Hasil pengamatan menunjukan bahwa sebagian siswa sudah memperhatikan penjelasan guru dengan antusias, berpartisipasi aktif dalam mengerjakan tugas kelompok, berani menyampaikan hasil di depan kelas, mampu menanggapi penyajian hasil diskusi dari kelompok lain, serta siswa juga mampu menjawab pertanyaan yang ditanyakan oleh guru mengenai materi yang sudah diajarkan. Secara ringkas, hasil pengamatan disajikan pada Tabel 4.

Tabel 4 Hasil pengamatan aktivitas belajar siswa pada Siklus II

\begin{tabular}{clcc}
\hline No & \multicolumn{1}{c}{ Indikator } & Jumlah & Persen \\
\hline 1 & Siswa mendengarkan penjelasan guru dengan antusias & 27 & 100,00 \\
2 & Siswa bekerja sama dalam kelompok & 27 & 100,00 \\
3 & Siswa berani menjawab pertanyaan dari guru & 23 & 85,19 \\
4 & Siswa melaporkan hasil ke depan kelas & 23 & 85,19 \\
5 & Siswa dapat membuat rangkuman pembelajaran & 23 & 85,19 \\
\hline
\end{tabular}

Penilaian juga dilakukan dengan tes objektif (10 pertanyaan). Hasil evaluasi disajikan pada Tabel 5.

Tabel 5 Hasil penelitian pada Siklus II

\begin{tabular}{clccl}
\hline No & \multicolumn{1}{c}{ Nama Siswa } & KKM & Nilai & \multicolumn{1}{c}{ Keterangan } \\
\hline 1 & Alan Malilo Putra & 60,00 & 60,00 & Tuntas \\
2 & Anggun Permata Sari & 60,00 & 90,00 & Tuntas \\
3 & Arif Okta Saputra & 60,00 & 100,00 & Tuntas \\
4 & Aulia Marliani & 60,00 & 80,00 & Tuntas \\
5 & Aditya Tri Wardana & 60,00 & 50,00 & Tidak Tuntas \\
6 & Azzahra Syakilla & 60,00 & 60,00 & Tuntas \\
7 & Fadhli Alfitra & 60,00 & 80,00 & Tuntas \\
8 & Fadhil Herya Pernanda & 60,00 & 70,00 & Tuntas \\
9 & Fuji Rahayu Liata & 60,00 & 90,00 & Tuntas \\
10 & Halim Maulana & 60,00 & 70,00 & Tuntas \\
11 & Habil Said & 60,00 & 80,00 & Tuntas \\
12 & Ikral Pernandes & 60,00 & 90,00 & Tuntas \\
13 & Imel Putri Aurelia & 60,00 & 60,00 & Tuntas \\
14 & Melly Indah Saputri & 60,00 & 80,00 & Tuntas \\
15 & Muh. Andra Ardiansyah & 60,00 & 70,00 & Tuntas \\
16 & Muh. Hidayat & 60,00 & 50,00 & Tidak Tuntas \\
17 & Naila Saputri & 60,00 & 100,00 & Tuntas \\
18 & Niani Anggraini & 60,00 & 80,00 & Tuntas \\
19 & Qonita Islamoza & 60,00 & 80,00 & Tuntas \\
20 & Refan Anugrah & 60,00 & 70,00 & Tuntas \\
21 & Septia Ramadhani & 60,00 & 80,00 & Tuntas
\end{tabular}




$\begin{array}{ll}22 & \text { Tika Ariski } \\ 23 & \text { Utari } \\ 24 & \text { Unggul Asmaul Husna } \\ 25 & \text { Vovi Norewan } \\ 26 & \text { Vila Abdillah } \\ 27 & \text { Wawan Askar } \\ & \text { Nilai Tertinggi } \\ & \text { Nilai Terendah } \\ & \text { Nilai Rata-Rata } \\ & \text { Ketuntasan Belajar }\end{array}$

Tabel 5 menginformasikan bahwa nilai terendah siswa adalah 50 dan nilai tertinggi adalah 100. Nilai rata-rata yang diperoleh 27 orang siswa adalah 74,81. Apabila dibandingkan antara nilai siswa dengan KKM kompetensi dasar maka diperoleh hasil bahwa sebanyak 23 orang siswa telah memiliki nilai yang lebih besar dari pada KKM kompetensi dasar. Artinya, sebanyak 23 orang siswa tuntas. Sisanya, sebanyak 4 orang siswa belum tuntas. Persentase ketuntasan belajar sebesar $85,19 \%$. Hasil ini menunjukkan bahwa terjadi peningkatan hasil belajar siswa setelah diberikan tindakan berupa penggunaan media gambar dibandingkan dengan saat pratindakan dan Siklus I.

Kegiatan keempat dalam siklus II adalah refleksi. Refleksi dari hasil penelitian adalah sebagai berikut:

1. Aktivitas dan hasil belajar siswa semakin membaik sehingga pelaksanaan penelitian dihentikan. Guru sebaiknya tetap melanjutkkan penggunaan model ini untuk meningkatkan aktivitas dan hasil belajar siswa.

2. Guru memberikan pengayaan pada siswa yang belum tuntas.

3. Guru sebaiknya meningkatkan pengetahuan tentang metode/model/strategi pembelajaran dan juga tentang media pembelajaran. Pengetahuan ini akan membantu guru dalam menerapkan metode/model/strategi pembelajaran yang beragam dan inovatif.

$\begin{array}{ccl}60,00 & 80,00 & \text { Tuntas } \\ 60,00 & 50,00 & \text { Tidak Tuntas } \\ 60,00 & 70,00 & \text { Tuntas } \\ 60,00 & 100,00 & \text { Tuntas } \\ 60,00 & 80,00 & \text { Tuntas } \\ 60,00 & 50,00 & \text { Tidak Tuntas } \\ & 100,00 & \\ & 50,00 & \\ & 74,81 & \\ & 85,19 & \end{array}$

4. Guru juga melakukan evaluasi pembelajaran baik proses maupun evaluasi hasil secara berkala untuk menjaga kualitas pembelajaran

5. Guru juga perlu memberikan motivasi pada siswa untuk meningkatkan kepercayaan dirinya

\section{Analisis Hasil Belajar Siswa}

Proses belajar dan mengajar memiliki tujuan-tujuan tertentu yang ingin dan harus dicapai. Baik atau buruknya suatu proses pembelajaran dapat diketahui dengan cara melakukan evaluasi hasil belajar pada siswa yang menjadi subjek utama dalam kegiatan pembelajaran. Hasil belajar adalah tingkat penguasaan yang dicapai oleh pelajar dalam mengikuti proses belajar mengajar sesuai dengan tujuan pendidikan yang ditetapkan (Hamalik, 2003). Dalam penelitian ini, hasil belajar siswa dinilai dari nilai ratarata kelas dan persentase ketuntasan belajar siswa. Hasil penelitian menunjukkan bahwa nilai rata-rata siswa sebelum diberikan tindakan adalah 50,74 dengan jumlah siswa yang tuntas atau memenuhi KKM kompetensi dasar adalah 13 orang. Setelah diberikan tindakan berupa penggunaan media gambar, hasil belajar siswa mengalami peningkatan. Hasil evaluasi Siklus I menunjukkan bahwa nilai rata-rata yang diperoleh siswa adalah 64,07 dengan jumlah siswa yang tuntas atau memenuhi KKM kompetensi dasar adalah 17 orang. Persentase ketuntasan belajar siswa juga meningkat dari $48,15 \%$ pada pratindakan menjadi $62,96 \%$ pada Siklus I. 
Guru melanjutkan pemberian tindakan pada siklus selanjutnya yaitu Siklus II. Hasil evaluasi pada Siklus II menunjukkan hasil yang memuaskan. Penggunaan media gambar kembali meningkatkan hasil belajar siswa. Hasil belajar siswa yang dicapai pada siklus II adalah 74,81 (nilai rata-rata) dan $85,19 \%$ (ketuntasan belajar). Hasil ini meningkat dibandingkan dengan hasil belajar siswa pada pratindakan dan Siklus I. Rekapitulasi hasil belajar siswa disajikan pada Gambar 1.

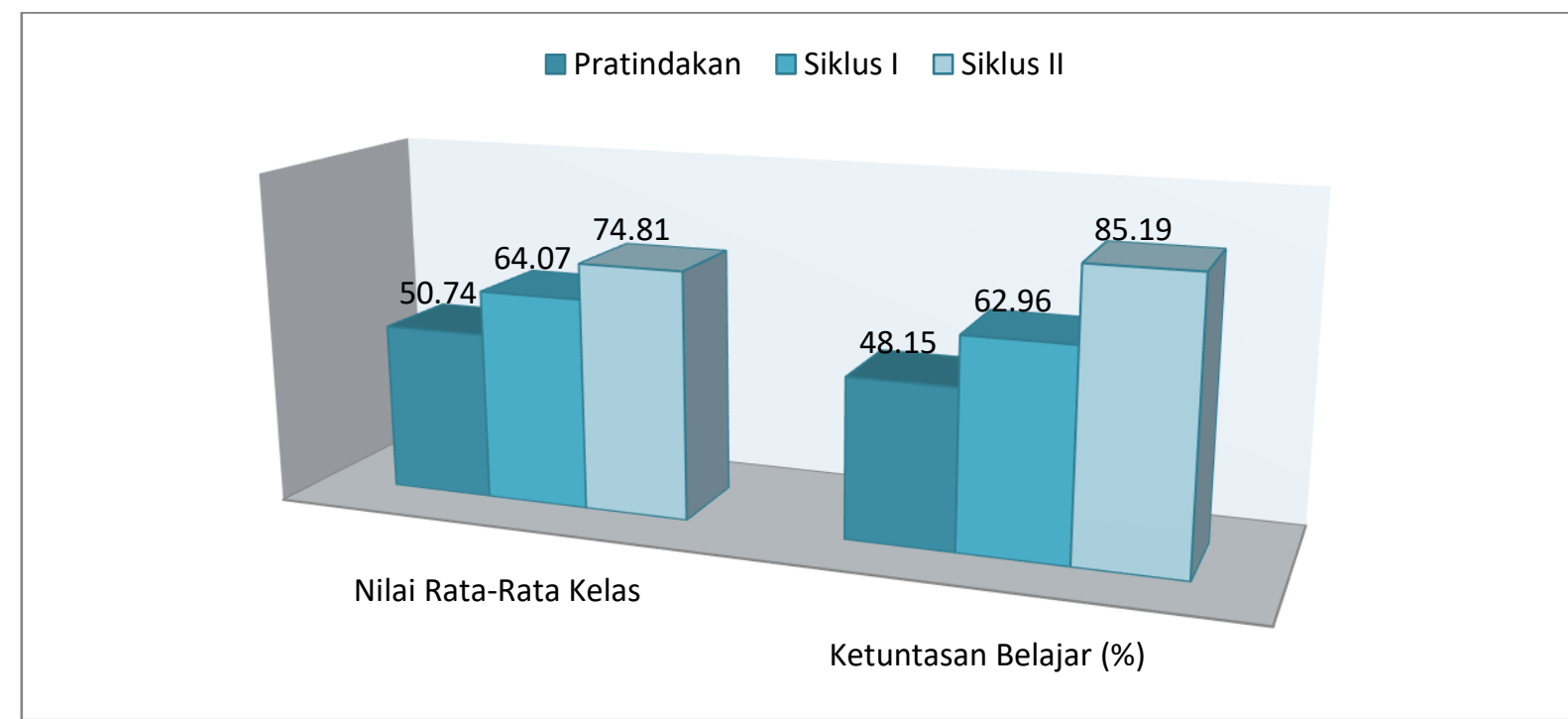

Gambar 1 Rekapitulasi hasil belajar siswa pada saat pratindakan, siklus I, dan siklus II

Hasil penelitian menunjukkan bahwa penggunaan media gambar dapat meningkatkan hasil belajar siswa kelas III di SDN. No. 031/XI Kampung Dalam tahun 2016/2017 pada mata pelajaran IPA, khususnya pada materi ciri-ciri dan kebutuhan makhluk hidup. Hasil ini menguatkan hasil penelitian yang telah dilakukan oleh guru di Sekolah lain, diantaranya adalah:

1. Nur (2010) yang menemukan bahwa pemanfaatan media gambar dapat meningkatkan hasil belajar IPA di kelas I SD Negeri Sidogiri I Kecamatan Kraton Kabupaten Pasuruan.

2. Ulumiyah (2010) yang menemukan bahwa pembelajaran IPA dengan media gambar dapat meningkatkan prestasi belajar siswa kelas II SDN Gunungsari Keacamatan Tajinan Kabupaten Malang.

3. Kasmawati, Kundera, dan Gagaramusu (2013) yang menemukan bahwa media gambar dapat meningkatkan hasil belajar IPA di kelas IV SD Inpres Banpres Posona

4. Sandra (2013) yang menemukan bahwa media gambar dapat meningkatkan aktivitas belajar siswa Kelas IV SDN Katelan 4 Sragen Tahun Ajaran 2012/2013.

5. Rinawati (2013) yang menemukan bahwa media gambar dapat meningkatkan hasil belajar IPA di kelas IV SD Negeri 12 Nasal.

6. Abdullah (2014) yang menemukan bahwa media gambar dapat meningkatkan aktivitas dan hasil belajar IPA di kelas V SD Inpres Watujara Tahun Pelajaran 2013/2014

7. Surahman, Paudi, dan Tureni (2015) yang menemukan bahwa media gambar dapat meningkatkan hasil belajar IPA di kelas II SD Alkhairaat Towera

8. Kapugu, Alibasyah, \& Sakung (2016) yang menemukan bahwa media gambar 
mampu meningkatkan hasil belajar siswa pada mata pelajaran IPA di kelas III SDN Santigi pada materi makhluk hidup.

\section{SIMPULAN}

Hasil penelitian menunjukkan bahwa terjadi peningkatan aktivitas dan hasil belajar. Aktivitas belajar siswa semakin membaik. Seluruh siswa telah mendengar penjelasan guru dan membentuk kelompok yang heterogen. Sebagian besar siswa juga telah dapat bekerja sama dalam kelompok, menjawab pertanyaan, dan menyampaikan hasil. Penggunaan media gambar membuat mahasiswa semakin aktif dalam kegiatan pembelajaran. Peningkatan juga terjadi pada hasil belajar. Peningkatan ini dapat dilihat dari peningkatan nilai rata-rata dan persentase ketuntasan belajar siswa. Nilai rata-rata siswa yang awalnya 50,74 meningkat menjadi 64,07 pada Siklus I, dan kembali meningkat menjadi 74,81 pada Siklus II. Demikian juga halnya dengan persentase ketuntasan belajar. Persentase ketuntasan belajar siswa yang awalnya $48,15 \%$ meningkat menjadi $62,96 \%$ pada Siklus I dan kembali meningkat menjadi $85,19 \%$ pada Siklus II. Dengan demikian, media gambar dapat menjadi alternatif bagi guru untuk meningkatkan hasil belajar siswa.

Berdasarkan hasil, penelitian ini menyarankan guru untuk memberikan pengayaan pada siswa yang belum tuntas. Guru sebaiknya meningkatkan pengetahuan tentang metode/model/strategi pembelajaran dan juga tentang media pembelajaran. Pengetahuan ini akan membantu guru dalam menerapkan metode/ model/strategi pembelajaran yang beragam dan inovatif. Guru juga melakukan evaluasi pembelajaran baik proses maupun evaluasi hasil secara berkala untuk menjaga kualitas pembelajaran Guru juga perlu memberikan motivasi pada siswa untuk meningkatkan kepercayaan dirinya. Saran lain juga ditujukan untuk sekolah. Sekolah diharapkan dapat memfasilitasi segala kebutuhan yang diperlukan guru untuk memperlancar proses pembelajaran.

\section{DAFTAR PUSTAKA}

Abdullah, A. N. 2014. Penggunaan Media Gambar untuk Meningkatkan Aktivitas dan Hasil Belajar IPA Siswa Kelas V SD Inpres WatujaraTahun Pelajaran 2013/2014 [Tesis]. Malang: Jurusan Pendidikan Guru Sekolah Dasar, Fakultas Ilmu Pendidikan, Universitas Negeri Malang.

Arikunto, Suharsimi, Suhardjono dan Supardi. 2014. Penelitian Tindakan Kelas. Jakarta: PT Bumi Aksara.

Darmodjo. 2009. Penggunaan Media Pembelajaran dalam Pembelajaran IPS di Sekolah Dasar. Bandung: IKIP Bandung

David, A. 2012. Ilmu Pengajaran : Taksonomi Variabel. Depdikbud: Jakarta

Hamalik, O. 2003. Proses Belajar Mengajar. Jakarta: Bumi Aksara.

Kapugu, Y., Alibasyah, L. M. P., \& Sakung, J. 2016. Meningkatkan Hasil Belajar Siswa Pada Mata Pelajaran IPA Melalui Penggunaan Media Gambar Di Kelas III SDN Santigi Pada Meteri Makhluk Hidup. Jurnal Kreatif Tadulako Online Vol. 4 No. 5, 69-83.

Kasmawati, Kundera, I. N., \& Gagaramusu, Y. 2013. Upaya Peningkatan Hasil Belajar Siswa pada Mata Pelajaran IPA Melalui Penggunaan Media Gambar di Kelas IV SD Inpres Banpres Posona. Jurnal Kreatif Tadulako Online Vol. 1 No. 2, 144-153.

Nur, A. 2010. Pemanfaatan Media Gambar Untuk Meningkatkan Hasil Belajar IPA di Kelas I SD Negeri Sidogiri I Kecamatan Kraton Kabupaten Pasuruan [Skripsi]. Malang: Program Studi Pendidikan Guru Sekolah Dasar, Jurusan Kependidikan 
Sekolah Dasar dan Pra Sekolah, Fakultas Ilmu Pendidikan, Univesitas Negeri Malang.

Rinawati, S. 2013. Upaya Peningkatkan

Prestasi Belajar Siswa Kelas IV SD

Negerii 12 Nasal, dengan Menggunakan Media Gambar Pokok Bahasan Mengenal Rangka Manusia pada Mata Pelajaran IPA Kelas IV SD Negeri 12 Nasal [Skripsi]. Bengkulu: Program Sarjana Kependidikan Guru Dalam Jabatan Fakultas Keguruan Dan Ilmu Pendidikan Universitas Bengkulu.

Sandra, P. K. A. 2013. Perbandingan Antara Penggunaan Media Gambar dengan Media Video terhadap Hasil Belajar Siswa Mata Pelajaran IPA Pada Siswa Kelas IV SDN Katelan 4 Sragen Tahun Ajaran 2012/2013 [skripsi]. Surakarta: Pendidikan Guru Sekolah Dasar, Fakultas Keguruan dan Ilmu Pendidikan, Universitas Muhammadiyah Surakarta.

Suprihatiningrum, J. 2014. Strategi Pembelajaran: Teori dan Aplikasi. Yogyakarta: Ar Ruzz Media.

Surahman, Paudi, R. I., \& Tureni, D. 2015. Meningkatkan Hasil Belajar Siswa Dalam Pembelajaran IPA Pokok Bahasan Makhluk Hidup dan Proses Kehidupan Melalui Media Gambar Kontekstual Pada Siswa Kelas II SD Alkhairaat Towera. Jurnal Kreatif Tadulako Online Vol. 3 No. 4, 91107.

Ulumiyah, L. M. 2010. Pembelajaran IPA Dengan Media Gambar untuk meningkatkan prestasi belajar siswa kelas II SDN Gunungsari Keacamatan Tajinan Kabupaten Malang [Skripsi]. Malang: Program Studi Pendidikan Guru Sekolah Dasar, Jurusan Kependidikan Sekolah Dasar dan Pra Sekolah, Fakultas Ilmu Pendidikan, Univesitas Negeri Malang. 